\title{
Androgen receptor and soy isoflavones in prostate cancer (Review)
}

\author{
MONIKA KMETOVÁ SIVOŇOVÁ ${ }^{1}$, PETER KAPLÁN ${ }^{1,2}$, ZUZANA TATARKOVÁ $^{1}$, \\ LUCIA LICHARDUSOVÁ ${ }^{2}$, RÓBERT DUŠENKA ${ }^{3}$ and JANA JUREČEKOVÁ ${ }^{2}$ \\ ${ }^{1}$ Department of Medical Biochemistry and ${ }^{2}$ Biomedical Center Martin, Jessenius Faculty of Medicine in Martin, \\ Comenius University in Bratislava, 03601 Martin; ${ }^{3}$ Department of Urology, Jessenius Faculty of Medicine and UHM \\ in Martin, Comenius University in Bratislava, 03601 Martin, Slovakia
}

Received July 26, 2018; Accepted November 16, 2018

DOI: $10.3892 / \mathrm{mco} .2018 .1792$

\begin{abstract}
Androgens and androgen receptor (AR) play a critical role not only in normal prostate development, but also in prostate cancer. For that reason, androgen deprivation therapy (ADT) is the primary treatment for prostate cancer. However, the majority of patients develop castration-resistant prostate cancer, which eventually leads to mortality. Novel therapeutic approaches, including dietary changes, have been explored. Soy isoflavones have become a focus of interest because of their positive health benefits on numerous diseases, particularly hormone-related cancers, including prostate and breast cancers. An important strategy for the prevention and/or treatment of prostate cancer might thus be the action of soy isoflavones on the AR signaling pathway. The current review article provides a detailed overview of the anticancer potential of soy isoflavones (genistein, daidzein and glycitein), as mediated by their effect on AR.
\end{abstract}

\section{Contents}

1. Introduction

2. AR: Structure, function and mechanism of action

3. Isoflavones: Structures, sources and general biological activities

4. Hormone-like properties of isoflavones

5. Isoflavones as AR modulators: Interactions with AR

6. Isoflavones as AR modulators: In vitro and in vivo studies and clinical trials on prostate cancer

7. Isoflavones and metabolism of steroid hormones

8. Conclusions

Correspondence to: Professor Monika Kmetová Sivoňová, Department of Medical Biochemistry, Jessenius Faculty of Medicine in Martin, Comenius University in Bratislava, Malá Hora 4D, 03601 Martin, Slovakia

E-mail: sivonova@jfmed.uniba.sk

Key words: androgen receptor, steroids, soy isoflavones, genistein, daidzein, glycitein, prostate cancer

\section{Introduction}

Prostate cancer is a major cause of disease and mortality among males; each year, 1.6 million men are diagnosed with prostate cancer and 366,000 men succumb to the disease. Genetic, epigenetic and environmental factors contribute to the development of prostate cancer (1). The progression of this hormone-dependent cancer is driven by androgens. Androgen deprivation therapy (ADT) is the primary treatment for advanced prostate cancer. ADT is initially highly effective but the majority of patients relapse and develop castration-resistant prostate cancer (CRPC) over 2-3 years, characterized by a lack of response to ADT (2). Increased expression of androgen receptor (AR) is one of the most frequent alterations observed in CRPC (3). This has been consistently associated with the development of resistance to anti-androgens and is the principal focus for prostate cancer prevention and treatment.

Data from several studies support an association between diet and cancer rates, with approximately $30-35 \%$ of cancer cases being associated with overnutrition or malnutrition (4). Epidemiological studies suggest that diet strongly contributes to variations in prostate cancer prevalence. The incidence and mortality of prostate cancer are low in Asian countries, with rates reported at approximately $1 / 8$ of that in Western countries (5). One possible explanation for this phenomenon is the high consumption of soy foods by Asian men as part of their regular diet.

The health benefits of isoflavones have been linked mostly to their antioxidant effects $(6,7)$. Although this is an important contributor, isoflavones also interact with other pathways, particularly receptor signaling (8). The most frequently investigated soy isoflavonic compound is genistein, followed by daidzein and equol. The protective effect of isoflavones against the development of prostate cancer has been demonstrated to be mediated by hormone-like effects via the binding of competitive estrogen receptors $\alpha$ and $\beta$ (ER- $\alpha$, ER- $\beta$ ) (9) and by non-hormone-like effects, including the inhibition of tyrosine kinases, modulation of cell proliferation, regulation of the cell cycle, apoptosis and angiogenesis, as well as tumor cell metastasis $(5,10,11)$.

Several molecular mechanisms, including the regulation of AR expression by soy isoflavones, have been investigated in animal and in vitro studies $(12,13)$. Human data are scarce regarding the effects of isoflavones on local AR expression in 
prostate cancer tissue and only the indirect effects of isoflavones on AR by blocking the expression of androgen-dependent genes, such as prostate specific antigen (PSA), have been examined in clinical studies (14). Furthermore, findings from epidemiological studies on the association between soy isoflavones and prostate cancer risk are incomplete and sometimes contradictory. The latest meta-analysis of 30 articles, comprising 15 case-control, 8 cohort and 7 nested case-control studies $(266,699$ total number of study participants and 21,612 patients), as performed by Applegate et al (15), demonstrated that total soy consumption is associated with a reduction of prostate cancer risk. The current review will summarize the existing knowledge and hypotheses concerning the mechanisms of soy isoflavones action on the AR signaling pathway in prostate cancer development.

\section{AR: Structure, function and mechanism of action}

AR, also known as NR3C4, is a ligand-activated intracellular transcription factor belonging to the family of steroid hormone receptors that also includes ER, glucocorticoid receptor, progesterone receptor and mineralocorticoid receptor (16). The AR gene is located on the X chromosome at q11-q12, contains 8 exons and codes for a protein with a molecular mass of approximately $110 \mathrm{kDa}$. Exon 1 encodes an $\mathrm{NH}_{2}$-terminal domain (NTD), exons 2 and 3 encode a DNA-binding domain (DBD), exon 4 encodes a hinge region and the remaining four exons encode the ligand-binding domain (LBD) (17).

The NTD is not well conserved; homology in this domain is only about $15 \%$ between the various steroid receptors. The activation function-1 (AF1) domain, located within the NTD, binds specific co-activators that facilitate the assembly of the transcription initiation complex (18). The AF1 is composed of two units: The ligand-dependent TAU-1 (amino acids 101-307) and the ligand-independent TAU-5 (amino acids 360-528). The full-length receptor requires a region primarily located between amino acids 141 and 338 for full ligand-inducible transcriptional activity (17). A growing number of coactivators and transcription factors have been reported to bind to the NTD AR-AF1 domain, including SRC-1, SRC-2, CBP, TFIIF and Sp1, and are thought to modulate protein-protein interactions $(19,20)$.

The DBD (amino acids 539-628) is highly conserved within the steroid receptor family and is essential for the function of the AR. It is composed of two zinc finger regions that facilitate direct AR binding as a dimer to the consensus inverted repeat androgen response element (ARE), GGTACAnnnTGTTCT, and to more complex response elements (21). The DBD is linked to the LBD by a hinge region. The sequence of this hinge domain is poorly conserved, although in all steroid receptors it contains a nuclear localization signal (NLS). In AR, the NLS is located between amino acids 617 and 633 and is responsible for the translocation of the receptor to the nucleus (22). The LBD mediates the interaction between AR and heat shock proteins and interacts with the $\mathrm{AR} \mathrm{NH}_{2}$ terminus to stabilize bound androgen. The LBD of the AR contains 11 helices (unlike other receptors that contain 12 helices; the AR lacks helix 2) and the AF2 domain (23).

AR is expressed in a diverse range of tissues, with androgens being documented as having significant biological actions in bone, muscle, prostate, adipose tissue and in the reproductive, cardiovascular, immune, neural and hematopoietic systems (24). In the absence of androgen ligands, the AR is cytoplasmic; it is associated with heat-shock proteins (Hsp90, Hsp70, Hsp56 and Hsp27) and other chaperone proteins that prevent it from entering the nucleus (25). The binding of androgen ligands, such as testosterone and the more potent dihydrotestosterone (DHT), to AR leads to a well-described series of events, including: i) Dissociation from heat-shock proteins; ii) rearrangement in the LBD inducing translocation to the nucleus and binding with co-regulatory factors through the AF2 region; iii) translocation to the nucleus and the formation of AR homodimers; iv) recognition/binding to ARE of AR target genes and formation of the AR-transcription complex with transcriptional activity through NTD-LBD interaction; and v) induction of androgen-responsive gene expression (18). A well-known gene regulated by AR is PSA, which is currently used as a biomarker for prostate cancer. In addition to PSA, AR regulates numerous genes that are involved in the regulation of proliferation and apoptosis.

$\mathrm{AR}$ is also subject to post-transcriptional modifications, including phosphorylation, acetylation, methylation, SUMOylation and ubiquitination together with phosphorylation. These post-transcriptional modifications alter AR functional activity, including transcriptional activity, stability and cellular localization (26).

The AR signaling pathway is essential for maintaining normal prostate growth, differentiation and function, and is an important component in the early pathogenesis of prostate cancer (27). Epidemiological data and clinical experience indicate that consumption of soy foods may contribute to prostate cancer prevention as a result of the hormonal properties of soy isoflavones, either through altered endogenous circulating hormones or hormone-receptor signaling (14). Little is known about the direct interaction of isoflavones with the AR. Their structural similarity with $17 \beta$-estradiol is evident, and hence, ER interaction has been postulated as a mechanism for their anticarcinogenic activity in prostate cancer (9). In the following sections, the anticancer potential of soy isoflavones, particularly in relation to their hormone-like properties and their effects on AR and prostate cancer risk, will be discussed.

\section{Isoflavones: Structures, sources and general biological activities}

Flavonoids are a large group of bioactive plant compounds exhibiting a variety of diverse structures (28). The general backbone for flavonoids consists of 15 carbon atoms arranged in two aromatic rings connected by a heterocyclic three-carbon ring. The degree of oxidation of the central pyrol ring differs and leads to the following sub-classification: Flavones, flavonols, isoflavones, flavanones, anthocyanins and flavanols, usually called catechins (29). In plant food products, the major forms are conjugated either with acid-alcohol or with glycosides, sometimes yielding highly complex structures (30). The diversity of flavonoid structures undoubtedly contributes to differences in biological efficacy with subtle differences affecting both bioavailability and bioactivity (31). The concept 
of bioavailability involves several variables, including intestinal absorption, metabolism by intestinal microflora, intestinal and hepatic metabolism, type and nature of circulating metabolites, binding to albumin, cellular uptake, accumulation in tissues and both biliary and urinary excretion (29). Whereas flavonoids are primarily recognized for their antioxidant functions, they also possess antimicrobial and anti-inflammatory activities (32-34). They have also been implicated in the prevention of neurodegenerative diseases (35), in the reduction of the risk of cardiovascular disease (32) and in decreased rates of certain types of cancer (36).

Dietary legumes, including black beans, lentils, lima beans, mung beans, and soybeans are sources of a variety of isoflavones, but only the soybean contains nutritionally relevant amounts of isoflavones (37). Many factors, including age, sex and food matrix, may influence intestinal metabolism and thereby the bioavailability of isoflavones in humans (38). The intestinal microflora plays a major role in the metabolism, bioavailability, biological activities and metabolomic profiles of dietary isoflavones. The human gastrointestinal tract harbors a community of 1,000 or more species of bacteria, amounting to $10^{14}$ cells, which is 10 times greater than the number of eukaryotic human cells (39). In vivo studies have indicated variations in health benefits of dietary isoflavones among individuals, which has been attributed to differences in the populations of colonic bacteria responsible for isoflavones conversion $(38,40,41)$. Various bacterial metabolites are known to be produced, among which some may exert biological activities (42).

Natural isoflavones are found in a biologically inactive form, namely as glucoconjugates (43). Following ingestion, isoflavone glucosides are hydrolyzed to active aglycones by glucosidases in the small intestine, within which the metabolites are absorbed completely or further metabolized into other metabolites, such as equol and $O$-desmethylangolensin, by the intestinal microflora in the large intestine. Nevertheless, only a fraction of aglycones can directly enter the circulation and become available to all other cells of the body. They persist in the plasma for $\sim 24 \mathrm{~h}$, with an average half-life of 6-8 $\mathrm{h}$ (44). Isoflavones are conjugated by UDP-glucuronosyltransferases and sulfotransferases in the liver. Once conjugated, isoflavones lose their functionality and are no longer bioactive. Therefore, the maximum bioavailability of active isoflavones is in the gut (45).

Genistein, daidzein and glycitein are the most common and well known isoflavones in nature (Fig. 1). They and their glycosides account for $\sim 50,40$ and $10 \%$, respectively, of the total isoflavone content of soybeans (46). The difference in isoflavone intake is notable between Asian and non-Asian countries. Generally, isoflavone content in food is measured as the sum of daidzein, genistein and glycitein in aglycone equivalents. For example, the usual mean daily isoflavone intake in Asians is $8-50 \mathrm{mg} /$ day but is $<3 \mathrm{mg} /$ day in the USA, Canada and Europe $(47,48)$.

The most studied isoflavone, genistein (5,7,4'-trihydroxyisoflavone, $\mathrm{C}_{15} \mathrm{H}_{10} \mathrm{O}$ ), has been reported to affect a spectrum of biological activities (Fig. 2). Genistein has been demonstrated to protect cells against oxidative stress by scavenging free radicals and chelate metals and is also able to strengthen the antioxidant defense system (49). Furthermore, genistein has been demonstrated to suppress tumor cell growth through the inhibition of DNA topoisomerases I and II, and protein tyrosine kinases $(10,50,51)$. Isoflavones have been identified to induce cell cycle arrest through various biological pathways. Genistein is reported to trigger cell cycle arrest in the G2/M phase and to induce cell apoptosis via mitochondrial damage with the involvement of the permeability transition pore and caspase-3 activation in T lymphoma cells (52), and through the inactivation of nuclear factor $(\mathrm{NF})-\kappa \mathrm{B}(53)$. Genistein inhibits $N F-\kappa B$ DNA binding via blocking phosphorylation of the inhibitory protein I $\kappa \mathrm{Ba}$, thereby preventing the nuclear

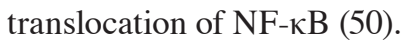

Another mechanism by which genistein can promote cancer cell death is via modulation of the regulation of proteins involved in cell cycle progression, namely the upregulation of cell cycle inhibitors or the downregulation of proteins that promote cell cycle progression. Certain studies in androgen-dependent or -independent prostate cancer cell lines have demonstrated that genistein mediates the transcriptional upregulation of p21 and p27, which are negative cell cycle regulators that act as cyclin-dependent kinase (CDK) inhibitors and cause cell cycle arrest and apoptosis (54-56). Genistein has also been identified to cause a reduction of CDK4 and a moderate inhibition of CDK2, cyclin D1 and cyclin E (57). In another study, a combination of genistein and daidzein was observed to increase p53 and to reduce cyclin $\mathrm{B} 1$ protein expression significantly in $\mathrm{LNCaP}$ prostate cancer cell lines (58). Furthermore, genistein treatment increased the expression of the pro-apoptotic protein Bax and decreased the expression of the anti-apoptotic proteins $\mathrm{Bcl}-2$ and $\mathrm{Bcl}-\mathrm{XL}$, leading to the induction of apoptotic cell death (59).

An important effect of isoflavones on cancer cells is the modulation of angiogenesis, which is essential for promoting the proliferation, invasion and metastasis of prostate cancer cells. Genistein has been demonstrated to cause significant basal and hypoxia-stimulated inhibition of the expression of vascular endothelial growth factor, which is a critical regulator of angiogenesis during prostate carcinogenesis in human prostate cancer PC-3 cells (60). Genistein and daidzein alter the expression of genes that are involved in angiogenesis and metastasis, including various matrix metalloproteinases (MMP-2, MMP-9, MMP-11, MMP-13, MMP-14 and membrane-type-MMP) (61), epidermal growth factor, angiopoietin-2, connective tissue growth factor and connective tissue activation peptide $(11,62)$

Genistein also inhibits the process of coagulation, a key promoter of plaque formation; this effect may be associated with the inhibition of growth factors such as platelet-derived growth factor, with subsequent effects on thrombin formation (63).

One of the most widely studied metabolites of daidzein is equol,(3S)-3-(4-hydroxyphenyl)-7-chromanol, which is produced by intestinal bacteria. In humans, $30-40 \%$ of the population can convert daidzein to equol (64). An established hypothesis is that equol-producers (individuals who can produce equol in response to the consumption of a soy diet) exhibit greater health benefits than equol-nonproducers (65). Equol exhibits strong antioxidant properties, with a greater antioxidant capacity compared with vitamin $C$ or $E$ observed in several in vitro tests (66), and the ability to regulate the cell cycle (14). Daidzein has been demonstrated to induce cell cycle arrest in the G0/G1 phase (11). 
<smiles>C[C@]12CC[C@@H]3c4ccc(O)cc4CC[C@H]3[C@@H]1CC[C@@H]2O</smiles>

17ß-estradiol<smiles>[R2]c1c(O)cc2occ(-c3ccc(O)cc3)c(=O)c2c1[R]</smiles>

Isoflavones

\begin{tabular}{|l|c|c|}
\hline & R1 & R2 \\
\hline Genistein & $\mathrm{OH}$ & $\mathrm{H}$ \\
\hline Daidzein & $\mathrm{H}$ & $\mathrm{H}$ \\
\hline Glycitein & $\mathrm{H}$ & $\mathrm{OCH}_{3}$ \\
\hline
\end{tabular}

Figure 1. Chemical structures of $17 \beta$-estradiol and isoflavones genistein, daidzein and glycitein.

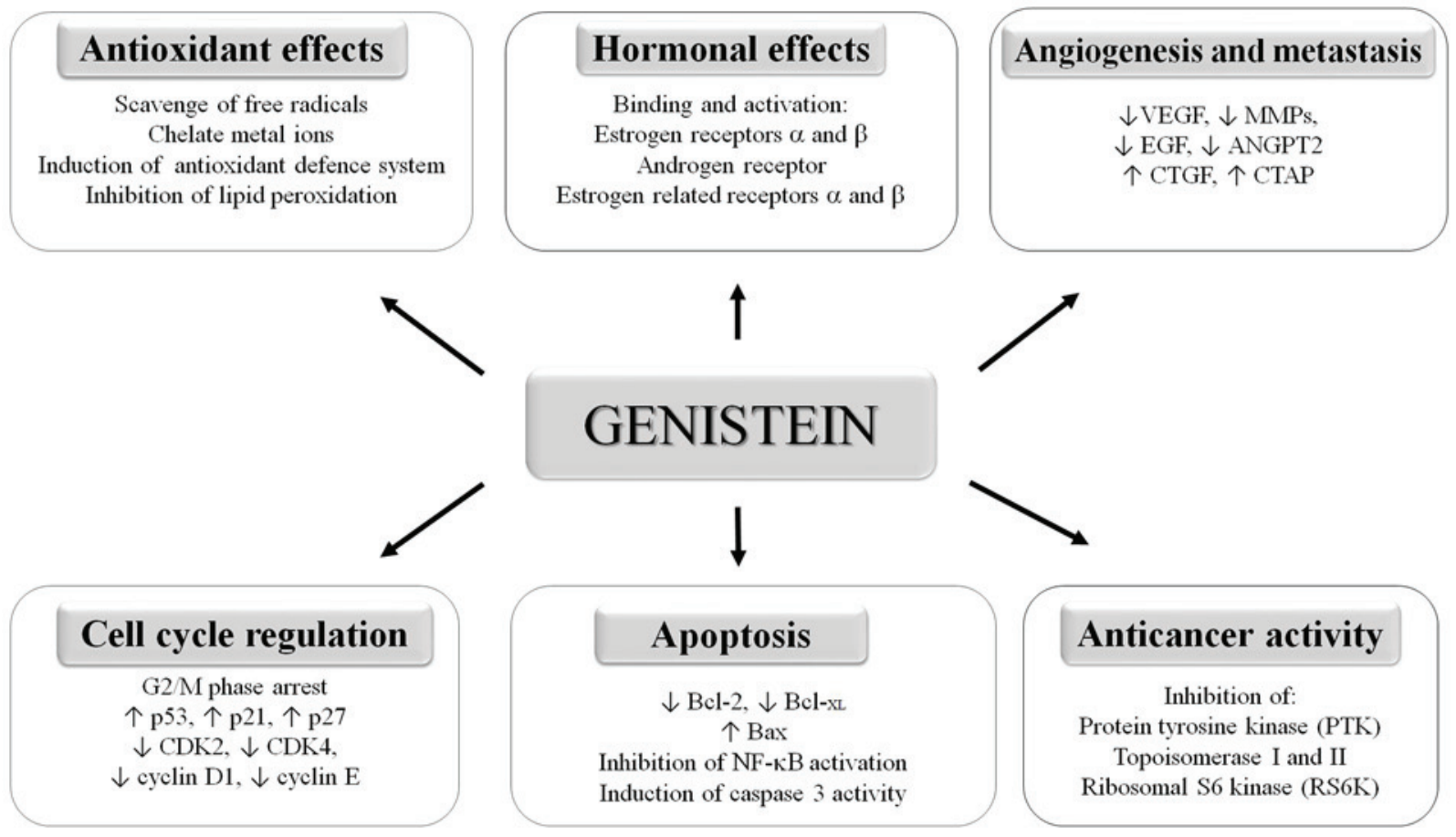

Figure 2. Overview of biological activities affected by genistein. Genistein is involved in cell proliferation, regulation of cell cycle, apoptosis, angiogenesis and tumor cell metastasis. Antitumorigenic effects of genistein occur mainly via interaction with estrogen receptors. It also exerts an antioxidant effect. $\uparrow$ indicates upregulation, $\downarrow$ indicates downregulation. VEGF, vascular endothelial growth factor; MMP, matrix metalloproteinase; EGF, epidermal growth factor; ANGPT2, angiopoietin 2; CTGF, connective tissue growth factor; CTAP, connective tissue activation peptide; CDK, cyclin-dependent kinase; NF-кB, nuclear factor- $\kappa \mathrm{B}$.

Glycitein has been identified to scavenge free radicals and thereby to prevent lipid peroxidation and DNA damage. It has also been demonstrated to inhibit the apoptosis of Chinese hamster lung fibroblast (V79-4) cells exposed to hydrogen peroxide $\left(\mathrm{H}_{2} \mathrm{O}_{2}\right)$ via radical scavenging activity (67).

\section{Hormone-like properties of isoflavones}

Numerous lines of evidence indicate that the antitumorigenic effects of isoflavones occur primarily via interaction with ERs (68). Isoflavones have structural similarities to estrogens, with hydroxyl groups in the $\mathrm{C} 7$ and $\mathrm{C} 4$ ' positions, like the 17ß-estradiol molecule (Fig. 1). These similarities explain the estrogenic activity of isoflavones, identify them as phytoestrogens (28) and confer their ability to bind ERs and sex-hormone-binding proteins. Isoflavones can thus exert both estrogenic and anti-estrogenic activity, the latter by competing for receptor binding by $17 \beta$-estradiol. Phytoestrogens have relatively weak activity compared with animal estrogens; however, exposure to high dietary levels may result in 
biological responses in humans and animals, with favorable or unfavorable consequences (69).

ER- $\alpha$ and $-\beta$ vary with respect to their tissue-specific expression and transcriptional activities. ER- $\alpha$ has been mainly found in the breast, ovarian stroma, endometrium and hypothalamus, whereas ER- $\beta$ has been mainly documented in the kidney, brain, bone, heart, lungs, intestinal mucosa, prostate and endothelial cells $(70,71)$. In normal prostate, ER- $\alpha$ is expressed in stromal cells and the basal cell layer, whereas ER- $\beta$ is predominantly expressed in luminal cells $(72,73)$.

Kuiper et al (9) investigated the ligand binding specificity of the two ER subtypes and identified that phytoestrogens have significantly higher affinities for ER- $\beta$, suggesting that this receptor subtype is more relevant to the action of non-steroidal estrogens. The exact position and number of the hydroxyl substituents on the isoflavone molecule seem to determine the ER-binding affinity. For example, the elimination of one hydroxyl group, as in daidzein, causes a great loss in binding affinity to ER- $\beta$ in comparison with the high binding affinity of genistein for ER- $\beta$ (74).

The binding affinity of genistein has been reported to be $4 \%$ for ER- $\alpha$ and $87 \%$ for ER- $\beta$ compared with estradiol (74). Thus, by interaction with ER, genistein concomitantly blocks the binding of more potent estrogens and affects estrogen metabolism, thereby exerting a potentially favorable role in the prevention of hormone-related cancers (75). An et al (76) demonstrated that genistein is $>1,000$-fold more potent at triggering transcriptional activity with ER- $\beta$ compared with ER- $\alpha$. These findings indicate that genistein is a potent agonist for ER- $\beta$ and that the divergent transcriptional actions of estrogens and isoflavones result not only from their different binding affinities, but also from the differences in their ability to recruit coregulators and trigger the transcriptional functions of ER- $\alpha$ and ER- $\beta$.

In vitro experiments suggest that equol is more estrogenic than daidzein (64). Muthyala et al (77) used competitive binding affinity assays to study the activities of the two equol enantiomers ( $\mathrm{S}$-equol and $\mathrm{R}$-equol) on the two estrogen receptors, ER- $\alpha$ and ER- $\beta$. It was demonstrated that the natural enantiomer, S-equol, had a high binding affinity, preferential for ER $\beta\left[\mathrm{K}_{\mathrm{i}}(\mathrm{ER}-\beta)=16 \mathrm{nM} ; \beta / \alpha=13\right.$ fold $]$, which is comparable to that of genistein $\left[\mathrm{K}_{\mathrm{i}}(\mathrm{ER}-\beta)=6.7 \mathrm{nM} ; \beta / \alpha=16\right]$, whereas R-equol bound more weakly and with a preference for $E R-\alpha\left[K_{i}(E R-\alpha)=50 n M ; \beta / \alpha=0.29\right]$. Furthermore, it was demonstrated that all equol isomers had a higher affinity for both ERs compared with the biosynthetic precursor daidzein, which exhibited little ER subtype selectivity. A later study by Setchell et al (78) also demonstrated that S-equol binds ER- $\beta$ at $\sim 20 \%$ of the affinity exhibited by $17 \beta$-estradiol (equol: $\mathrm{K}_{\mathrm{i}}=0.7$ $\mathrm{nM}$; $17 \beta$-estradiol: $\mathrm{K}_{\mathrm{d}}=0.15 \mathrm{nM}$ ), whereas the $\mathrm{R}$ enantiomer is relatively inactive.

Little is known about the activation of ERs by glycitein, which has been demonstrated to have weak estrogenic activity comparable with that of the other soy isoflavones, but at a much lower level compared with that of $17 \beta$-estradiol (79).

\section{Isoflavones as AR modulators: Interactions with $A R$}

The mechanisms of action of isoflavones on the AR are largely unclear and little is known about the direct interaction of isoflavones with the AR. The current review highlights published data relating to the possible effects of isoflavones on the AR signaling pathway (Fig. 3). Bektic et al (12) analyzed the binding of genistein to the AR by a binding assay with radioactively labelled androgen (methyltrienologen, R1881). They have revealed that the inhibition of specific androgen binding is $<25 \%$ at genistein concentrations above $100 \mathrm{nM}$. It was also postulated that the effect of genistein on AR expression is mediated by ER- $\beta$. Subsequently, using an in silico computerized docking model, it was determined that genistein and daidzein fit well into the LBD domain of AR and that their binding position is the same as that used by estradiol and DHT. It has also been identified that genistein and daidzein can be considered as strong candidates in two key aspects of ligand-receptor binding, namely the binding position and affinity energy (genistein, $-8.5 \mathrm{kcal} / \mathrm{mol}$; daidzein, $-8.7 \mathrm{kcal} / \mathrm{mol}$ ). Thus, genistein and daidzein are regarded as AR-related factors (80).

Equol, as a metabolite of daidzein, has been shown not to bind the prostatic AR; the anti-androgenic action of equols is attributable to their unique ability to bind DHT, specifically leading to the sequestration of DHT from binding to the AR (81). A study by Itsumi et al (82) demonstrated that equol induces AR degradation via the proteasomal pathway through Skp2, which is a ubiquitin ligase, but not through transcriptional or translational mechanisms.

In the absence of the AR ligand DHT in the cytoplasm, AR binding to heat shock proteins (including Hsp90) is an important step in the stabilization of the three-dimensional structure of AR in a conformation that permits androgen binding (83). Basak et al (84) demonstrated using LNCaP cells that the inhibitory effect of genistein on HDAC6, which is a Hsp90 deacetylase, results in a decrease in the activity of Hsp90 by affecting its acetylation status. Hence, treatment with genistein leads to increased acetylated Hsp90, resulting in AR degradation by directing AR for ubiquitination. In addition, the inhibition of ATP binding to Hsp90 can destabilize complex Hsp90-client proteins (including AR) and ultimately result in AR degradation (85).

Furthermore, ligand-AR complex translocation to the nucleus can be affected by isoflavones. Li et al (86) have reported that AR activity is regulated by isoflavones through Akt/Forkhead transcription factor class O3a/glycogen

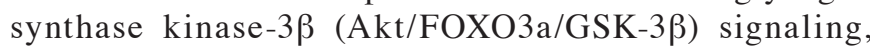
resulting in the inhibition of AR translocation into the nucleus and thereby promoting AR degradation. They also suggest that the isoflavone-induced inhibition of cell proliferation and the induction of apoptosis are partly mediated through regulation of the Akt/FOXO3a/GSK-3 $\beta /$ AR signaling network.

\section{Isoflavones as $\mathrm{AR}$ modulators: In vitro and in vivo studies and clinical trials on prostate cancer}

In vitro cell line experiments and in vivo animal studies have demonstrated that isoflavones affect a number of molecular mechanisms, including the regulation of AR gene expression. Some of these studies have indicated that isoflavone mixtures or isolated/individual isoflavones (most often genistein) decrease AR mRNA and/or protein levels $(12,13,84)$, whereas others have revealed that the effect is largely at the 


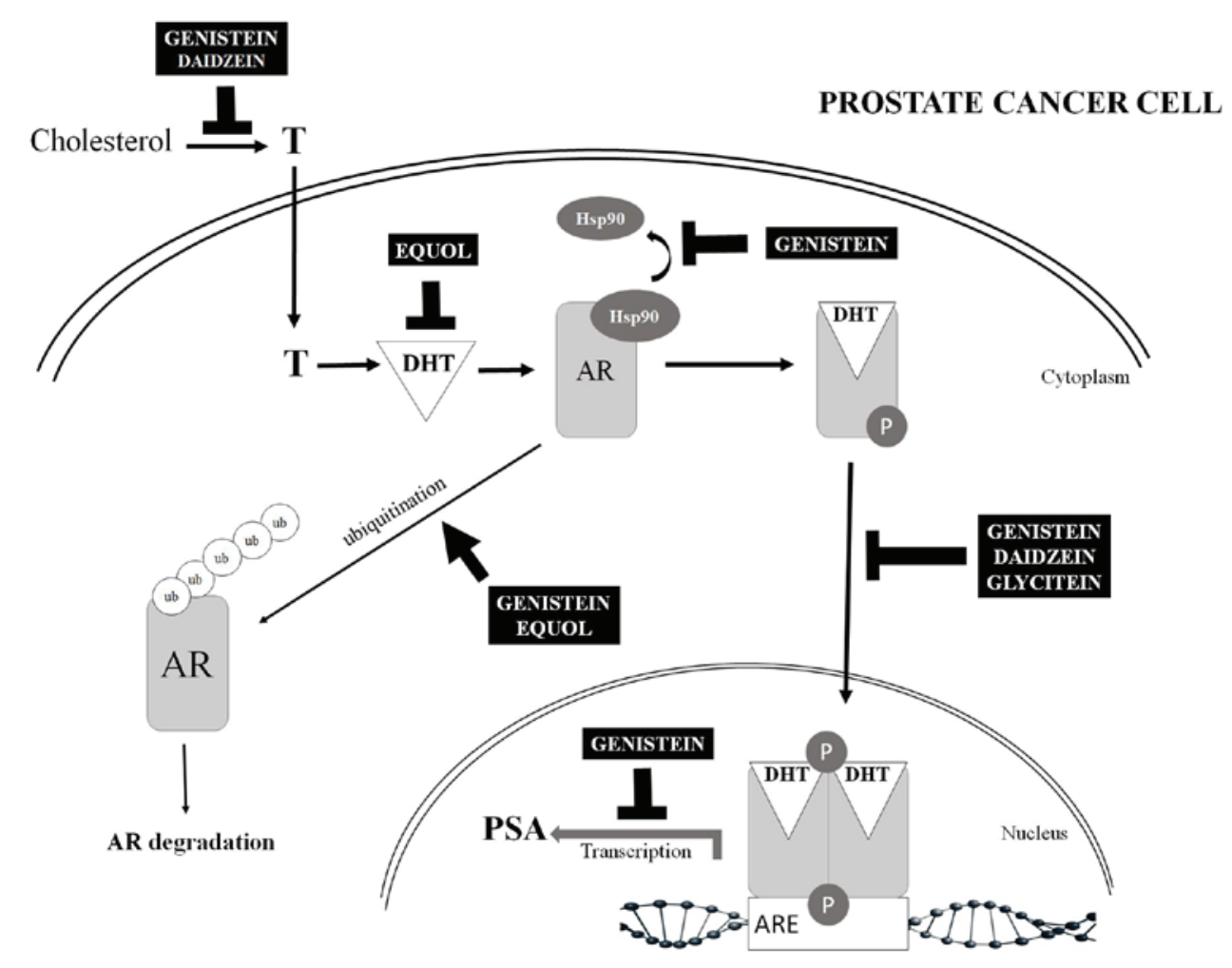

Figure 3. AR signaling pathway and the possible effect of soy isoflavones. Several possible mechanisms have been proposed to explain the mechanism by which isoflavone activity affects AR. Possible mechanism include the transcriptional regulation of AR, the induction of AR degradation by the proteasomal pathway and the inhibition of ligand-AR complex translocation to the nucleus, leading to the possible inhibition of nuclear AR binding to ARE and thereby triggering an effect on the transcription of androgen-dependent genes (e.g., PSA). Indirect effects of isoflavones on AR may also be mediated by affecting the synthesis of testosterone, its conversion to DHT and the sequestration of DHT from binding AR, thereby reducing prostate cancer risk. $\uparrow$ indicates induction; $\perp$ indicates inhibition. AR, androgen receptor; ARE, androgen response element; DHT, dihydrotestosterone; Hsp90, heat-shock protein 90; PSA, prostatic-specific antigen; ub, ubiquitin; T, testosterone.

protein level, depending on the concentration and the duration of isoflavone treatment and on the mutational status of the AR (87). By contrast, genistein at low concentrations has been reported to transactivate the endogenous $\mathrm{AR}$ in $\mathrm{LNCaP}$ cells, increasing the transcriptional potential with a higher receptor expression (88). Later studies have also identified stimulatory effects of genistein on AR expression $(87,89)$. Mahmoud et al (90) demonstrated that genistein exerts a pleiotropic effect on prostate cancer cell proliferation and AR activity depending on the AR status of the cells. In a dose-dependent manner, genistein inhibits cell proliferation and AR nuclear localization and expression in LAPC-4 cells with a wild-type AR. However, in LNCaP cells, lower doses of genistein exert growth stimulatory effects and enhance AR expression.

These conflicting reports concerning the effect of genistein on AR expression may be attributable to differences in the various hormone-responsive cancer cell lines, the type of LNCaP cells used, the mostly pharmacological genistein concentrations used in most of these studies or other methodological limitations. In most studies, $\mathrm{LNCaP}$ cells have been utilized. This cell line has a threonine to alanine (T877A) mutation in the LBD domain of the AR, is androgen-sensitive and proliferates in response to AR activation (91). In this cell line, ER- $\beta$ is highly expressed, whereas ER- $\alpha$ expression is relatively low or undetectable (92). Genistein, with its estradiol-like structure, has been hypothesized to be a ligand for this mutant AR; this potentially explains the stimulatory effects that have been obtained when using LNCaP cells in certain studies (90). DNA microarray analyses in LNCaP cells have also indicated that the lowest concentrations of genistein alter gene expression in the AR pathway in a gene-specific and selective manner (93).

The effect of dietary genistein at concentrations comparable with those found in humans consuming a soy diet on sex steroid receptor expression in the dorsolateral prostate has been studied in vivo in male Sprague-Dawley rats by Fritz et al (13). The dorsolateral lobes of the rat prostate are the most similar to the human prostate peripheral zone, in which the majority of prostate tumors develop. The study indicated a direct dose-dependent downregulation of AR mRNA expression by genistein. However, this effect of genistein on AR gene expression has not been confirmed in a transgenic mouse model of prostate cancer (94).

The protective role of daidzein on flutamide-induced androgen deprivation on AR expression was studied in male Wistar rats. Sub-chronic (60 days) flutamide (30 $\mathrm{mg} / \mathrm{kg}$ body weight) administration resulted in a marked decrease in AR expression (mRNA and protein levels). The administration of daidzein significantly and dose-dependently restored the AR expression, as was further confirmed by immunohistochemistry (95). Equol was identified not to alter AR mRNA expression in male rat prostate (96). Another investigation demonstrated no 
effect of a low-level $(10 \mathrm{mg} / \mathrm{kg})$ or high-level $(600 \mathrm{mg} / \mathrm{kg})$ isoflavone-containing diet on AR gene expression in the prostate of male Noble rats (97).

To date, few in vitro studies have provided even indirect evidence concerning the effect of isoflavones on AR by investigation of the ability of isoflavones to block androgenic activities, such as the expression of androgen-dependent genes (Fig. 3). PSA is well known as being an androgen-regulated gene and a marker for AR activity (12). The reduction of PSA expression in LNCaP cells by genistein first observed by Onozawa et al (98) was confirmed by later studies $(87,93)$. The inhibitory effect of genistein on PSA and AR protein levels was not observed with daidzein. Davis et al (99) have employed a $\mathrm{VeCaP}$ cell line, which expresses PSA in an androgen-independent manner, and identified that only high concentrations of genistein inhibit PSA expression in these cells. In a study by Peternac et al (100), genistein was observed to inhibit PSA protein expression in $\mathrm{LNCaP}$ and in $\mathrm{LNCaP}$-derived CRPC C4-2B cells, but altered PSA mRNA expression occurred only in $\mathrm{LNCaP}$ cells.

Despite evidence from in vitro studies, human intervention studies report inconsistent effects of soy or soy isoflavone consumption on AR activity and PSA levels in men. Table I summarizes studies on soy isoflavones and prostate cancer (101-114). Systematic reviews of double-blind placebo-controlled randomized clinical trials $(15,115-117)$ have summarized current human data that provide evidence for several anti-cancer properties of dietary supplements, including isoflavones, in reference to prostate cancer. Certain studies have indicated that the administration of isoflavone supplements does not change PSA concentrations, but not all studies come to this conclusion. Several of these studies, including those that found no change in PSA and ones that did find a change, were limited with respect to study design, sample size, dose administered and/or isoflavone concentrations achieved in the body. Another very important question is if the duration of a study was sufficient to detect clinically meaningful changes in the endpoints of interest, as progression from prostatic intraepithelial neoplasia to high grade prostatic intraepithelial neoplasia and early latent cancer may take 10 or more years, and clinically significant carcinoma may not occur for another 3-15 years, while recurrent disease may take a decade or more to manifest (116).

\section{Isoflavones and metabolism of steroid hormones}

The indirect effect of isoflavones on AR has been hypothesized to also be mediated by their effect on endogenous androgen levels and thereby that they reduce prostate cancer risk (Fig. 3). Short exposure to high concentrations of daidzein has been demonstrated to lead to reduced testosterone levels in vitro and to exert adverse effects on Sertoli cells in neonatal mouse testes (118). Furthermore, genistein has been reported to impair early testosterone production in fetal mouse testes in vitro (119). Few previous animal studies have focused on the effects of isoflavones on testosterone biosynthesis, whereas most of them have shown that the administration of isoflavones decrease the secretion of androgens (120-122).

Data from randomized controlled trials on the efficacy and safety of soy or soy isoflavones in men with prostate cancer or with a clinically identified risk of prostate cancer are inconsistent. A small number of reports show a significant association of isoflavone consumption on changes in circulating hormone profiles [total testosterone, free testosterone, sex hormone binding globulin (SHBG), DHT and free androgen index] $(102,103)$ but most studies $(110,113,114,123)$ and the meta-analyses to date have not found any association $(116,124)$. Isoflavones may stimulate the production of SHBG in the liver and bind to biologically active testosterone. This may lead to the lowering of free testosterone levels and its bioavailability to the target prostate cells and should theoretically halt cancer cell proliferation and inhibit tumor progression $(125,126)$. In a nested case-control study of Japanese men who consume soy isoflavones in large quantities, no overall association was observed between the plasma levels of total testosterone and SHBG and total prostate cancer (127). An opposite effect of the constant daily consumption of isoflavone supplements has been observed in healthy Japanese men; the serum levels of SHBG significantly increase and the serum levels of free testosterone and DHT decrease significantly after a 3-month supplementation (128).

Isoflavones may also influence the metabolism of steroid hormones by inhibiting the activity of enzymes in the steroidogenic pathway. Bae et al (129) have shown that genistein and equol have a higher inhibitory effect on rat prostate testosterone $5 \alpha$-reductase (an enzyme that metabolizes testosterone to DHT) compared with daidzein and glycitein. Other enzymes involved in the conversion of cholesterol to testosterone, such as cytochrome $\mathrm{P} 450$ cholesterol side-chain cleavage enzyme, $3 \beta$-hydroxysteroid dehydrogenase isoform, cytochrome $\mathrm{P} 450$ $17 \alpha$-hydroxylase/17-20 lyase and 17 $\beta$-hydroxysteroid dehydrogenase 3, may be affected by isoflavones (130-132).

\section{Conclusions}

AR, together with androgens, plays a major role in cell proliferation and differentiation during prostate development and in prostate cancer development and progression. Consumption of isoflavones is associated with a reduced risk of prostate cancer but the direct effects of isoflavones on the AR signaling pathway are not well understood. Isoflavones are assumed to exert multiple mechanisms to affect AR, such as the transcriptional regulation of AR, the inhibition of AR translocation to the nucleus, the inhibition of testosterone synthesis and its conversion to DHT and, thereby, an effect on the transcription of androgen-dependent genes (e.g., PSA), leading to the induction of apoptosis and the inhibition of cancer cell growth. To date, although overwhelming data from animals and from in vitro studies, epidemiological studies and case-control studies indicate that soy isoflavones have the potential to reduce prostate cancer risk, further studies are required in order to improve our understanding of the isoflavone action on the AR signaling pathway. Furthermore, large clinical trials with sufficient statistical power are required to assess whether isoflavone supplementation is able to reduce prostate cancer development or progression.

\section{Acknowledgements}

Not applicable. 


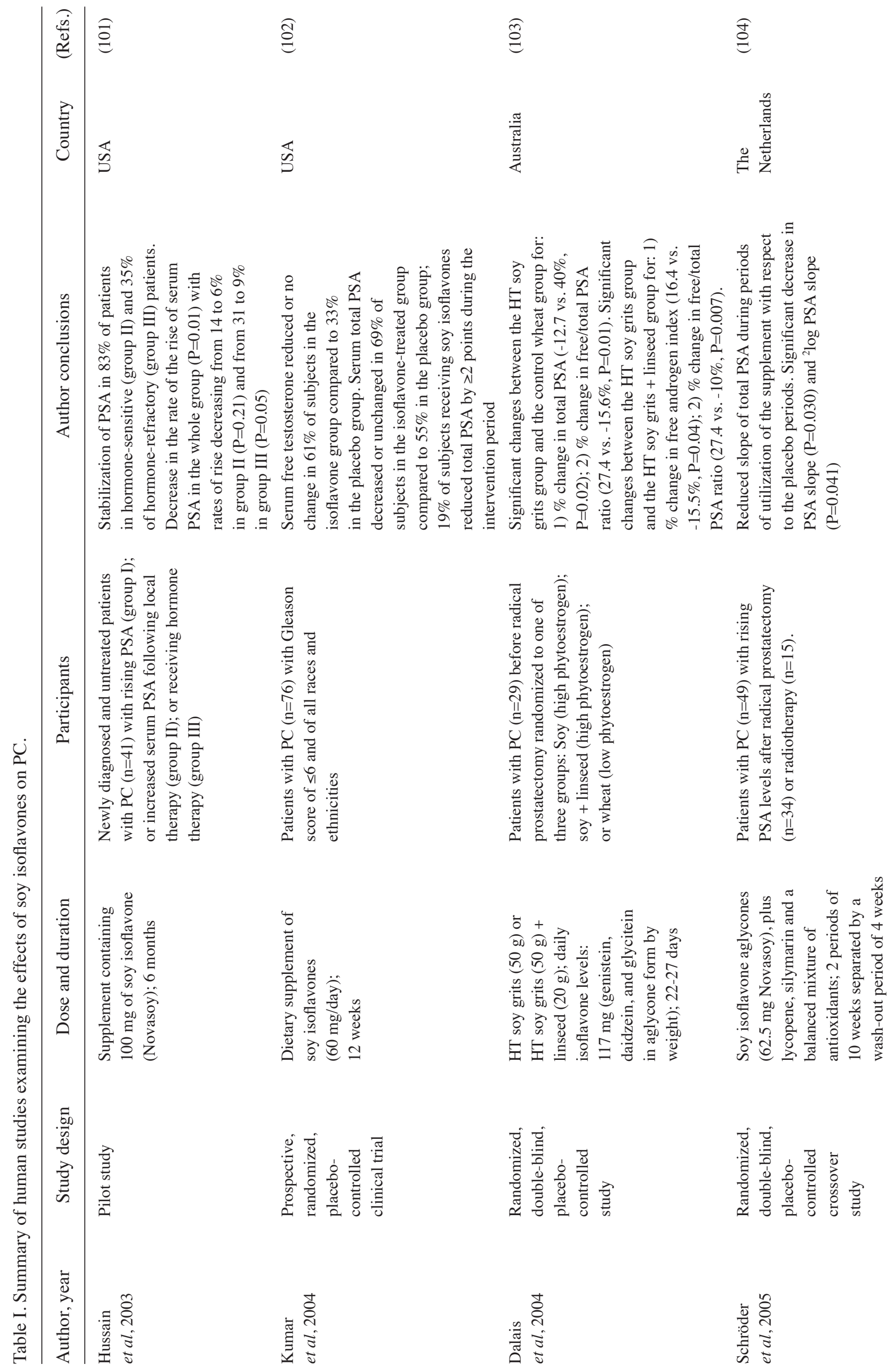




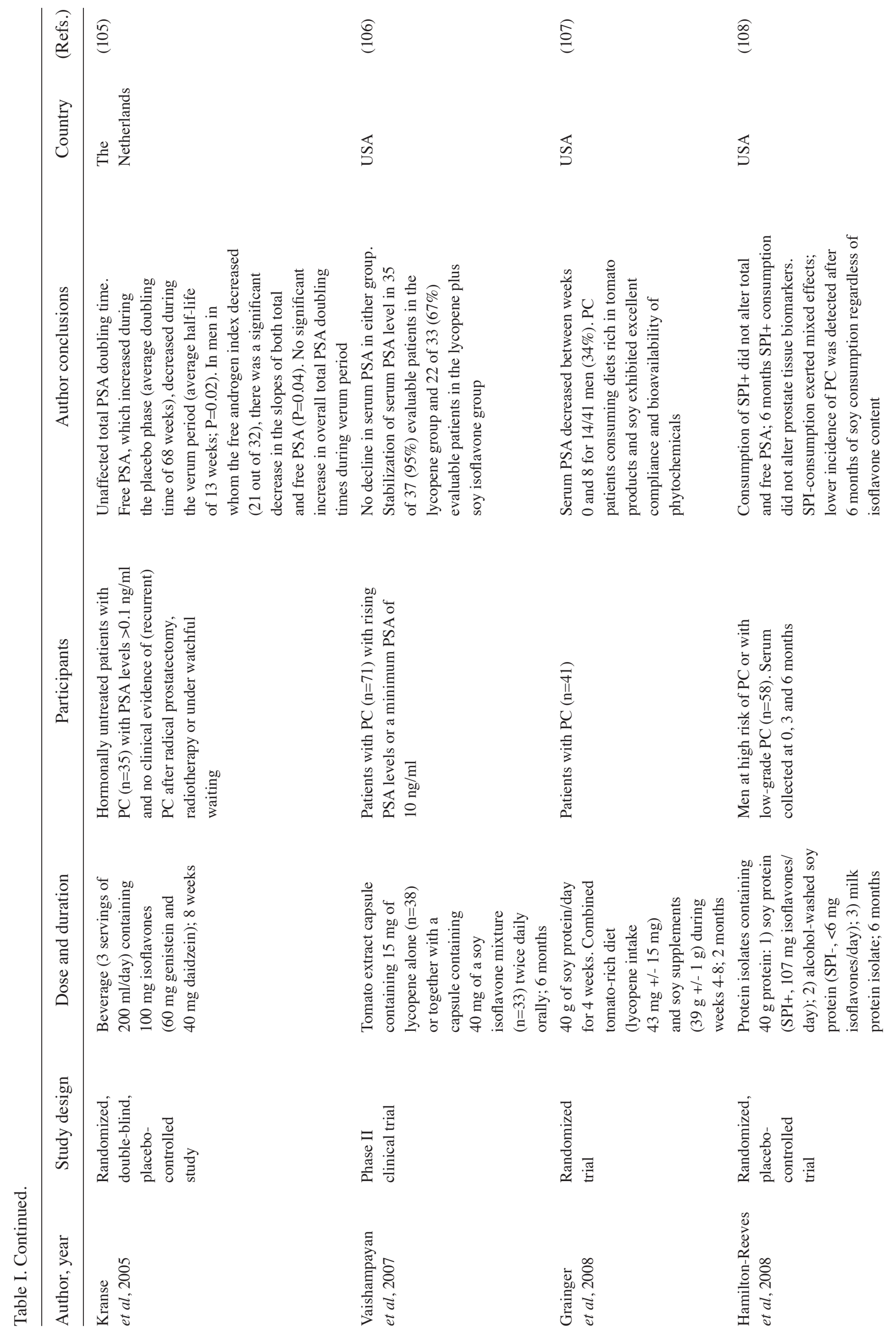




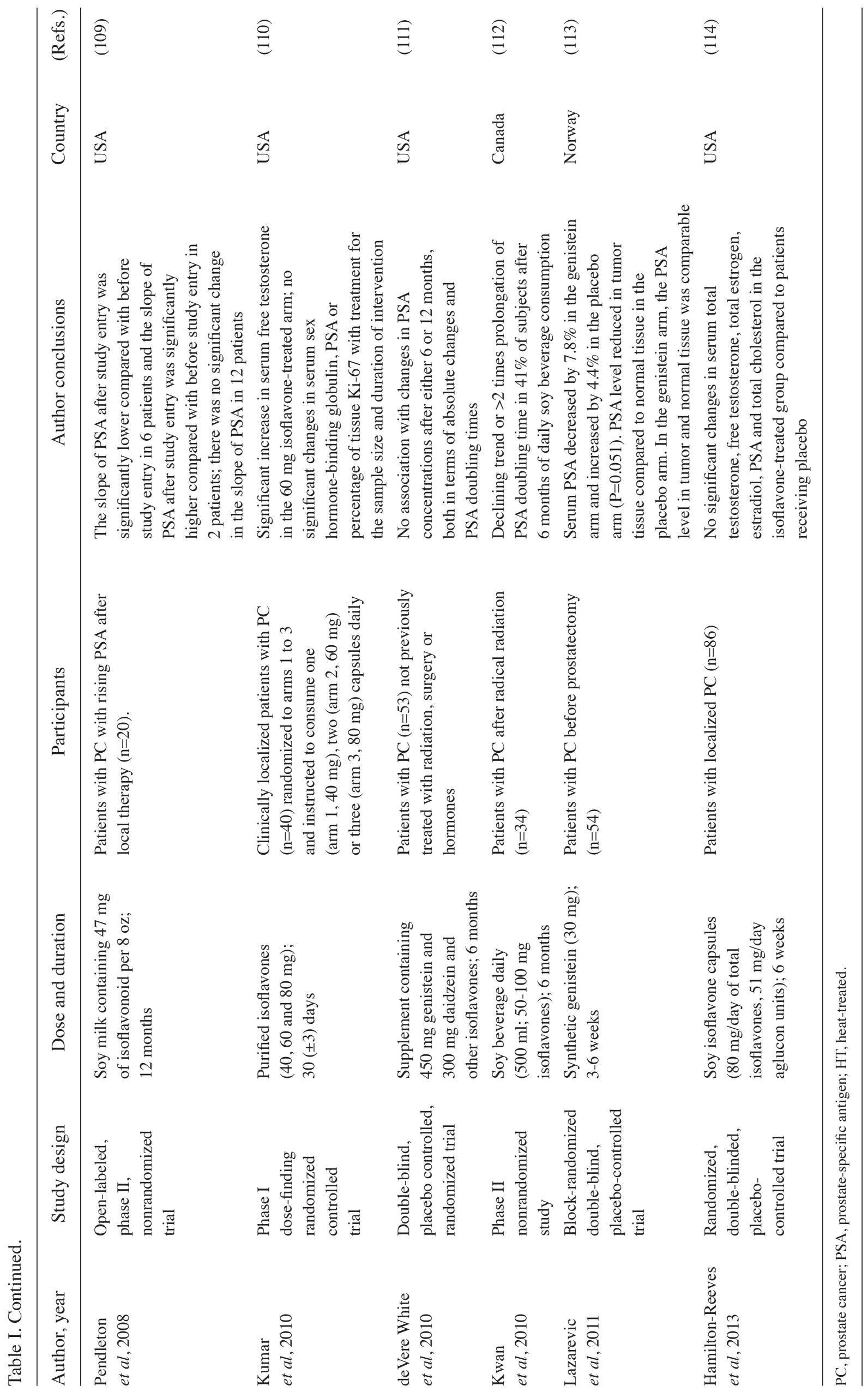




\section{Funding}

This review was supported by the Agency of Ministry of Education, Science, Research and Sport of the Slovak Republic under (grant no. 1/0172/18) and the Center of Translational Medicine project (grant no. ITMS 26220220021), co-financed from EU sources.

\section{Availability of data and materials}

Not applicable.

\section{Authors' contributions}

MKS, JJ and PK formulated the focus of the review and wrote the manuscript; ZT and LL conducted the literature search; RD prepared the figures; and MKS coordinated preparation of the manuscript and prepared the final version. All authors read and approved the final manuscript.

\section{Ethics approval and consent to participate}

Not applicable.

\section{Patient consent for publication}

Not applicable.

\section{Competing interests}

The authors declare that they have no competing interests.

\section{References}

1. Pernar CH, Ebot EM, Wilson KM and Mucci LA: The epidemiology of prostate cancer. Cold Spring Harb Perspect Med 8 pii: a030361, 2018

2. Mitsuzuka K and Arai Y: Metabolic changes in patients with prostate cancer during androgen deprivation therapy. Int $\mathrm{J}$ Urol 25: 45-53, 2018.

3. Grasso CS, Wu YM, Robinson DR, Cao X, Dhanasekaran SM, Khan AP, Quist MJ, Jing X, Lonigro RJ, Brenner JC, et al: The mutational landscape of lethal castration-resistant prostate cancer. Nature 487: 239-243, 2012.

4. Sung B, Prasad S, Yadav VR, Lavasanifar A and Aggarwal BB Cancer and diet: How are they related? Free Radic Res 45 864-879, 2011

5. Zhang HY, Cui J, Zhang Y, Wang ZL, Chong T and Wang ZM Isoflavones and prostate cancer: A review of some critical issues. Chin Med J (Engl) 129: 341-347, 2016.

6. Patel RP, Boersma BJ, Crawford JH, Hogg N, Kirk M, Kalyanaraman B, Parks DA, Barnes S and Darley-Usmar V: Antioxidant mechanisms of isoflavones in lipid systems: Paradoxical effects of peroxyl radical scavenging. Free Radic Biol Med 31: 1570-1581, 2001.

7. Yen GC and Lai HH: Inhibition of reactive nitrogen species effects in vitro and in vivo by isoflavones and soy-based food extracts. J Agric Food Chem 51: 7892-7900, 2003.

8. Braakhuis AJ, Campion P and Bishop KS: Reducing breast cancer recurrence: The role of dietary polyphenolics. Nutrients 8 : pii: E547, 2016.

9. Kuiper GG, Carlsson B, Grandien K, Enmark E, Häggblad J, Nilsson S and Gustafsson JA: Comparison of the ligand binding specificity and transcript tissue distribution of estrogen receptors alpha and beta. Endocrinology 138: 863-870, 1997.

10. Akiyama T, Ishida J, Nakagawa S, Ogawara $\mathrm{H}$, Watanabe $\mathrm{S}$, Itoh N, Shibuya M and Fukami Y: Genistein, a specific inhibitor of tyrosine-specific protein kinases. J Biol Chem 262: 5592-5595, 1987.
11. Rabiau N, Kossaï M, Braud M, Chalabi N, Satih S, Bignon YJ and Bernard-Gallon DJ: Genistein and daidzein act on a panel of genes implicated in cell cycle and angiogenesis by polymerase chain reaction arrays in human prostate cancer cell lines. Cancer Epidemiol 34: 200-206, 2010.

12. Bektic J, Berger AP, Pfeil K, Dobler G, Bartsch G and Klocker H: Androgen receptor regulation by physiological concentrations of the isoflavonoid genistein in androgen-dependent LNCaP cells is mediated by estrogen receptor beta. Eur Urol 45: 245-251, 2004.

13. Fritz WA, Wang J, Eltoum IE and Lamartiniere CA: Dietary genistein down-regulates androgen and estrogen receptor expression in the rat prostate. Mol Cell Endocrinol 186: 89-99, 2002.

14. Mahmoud AM, Yang W and Bosland MC: Soy isoflavones and prostate cancer: A review of molecular mechanisms. J Steroid Biochem Mol Biol 140: 161-132, 2014.

15. Applegate CC, Rowles JL, Ranard KM, Jeon S and Erdman JW: Soy consumption and the risk of prostate cancer: An updated systematic review and meta-analysis. Nutrients 10: pii: E40, 2018.

16. Kumar R: Steroid hormone receptors and prostate cancer: Role of structural dynamics in therapeutic targeting. Asian J Androl 18: 682-686, 2016

17. Jenster G, van der Korput HA, Trapman J and Brinkmann AO Identification of two transcription activation units in the $\mathrm{N}$-terminal domain of the human androgen receptor. J Biol Chem 270: 7341-7346, 1995.

18. Kumar R and McEwan IJ: Allosteric modulators of steroid hormone receptors: Structural dynamics and gene regulation. Endocr Rev 33: 271-299, 2012.

19. Monaghan AE and McEwan IJ: A sting in the tail: The $\mathrm{N}$-terminal domain of the androgen receptor as a drug target. Asian J Androl 18: 687-694, 2016.

20. Lavery DN and McEwan IJ: Functional characterization of the native $\mathrm{NH} 2$-terminal transactivation domain of the human androgen receptor: Binding kinetics for interactions with TFIIF and SRC-1a. Biochemistry 47: 3352-3359, 2008.

21. Verrijdt G, Tanner T, Moehren U, Callewaert L, Haelens A and Claessens F: The androgen receptor DNA-binding domain determines androgen selectivity of transcriptional response. Biochem Soc Trans 34: 1089-1094, 2006.

22. Zhou ZX, Wong CI, Sar M and Wilson EM: The androgen receptor: An overview. Recent Prog Horm Res 49: 249-274, 1994.

23. Matias PM, Donner P, Coelho R, Thomaz M, Peixoto C, Macedo S, Otto N, Joschko S, Scholz P, Wegg A, et al: Structural evidence for ligand specificity in the binding domain of the human androgen receptor. Implications for pathogenic gene mutations. J Biol Chem 275: 26164-26171, 2000.

24. Davey RA and Grossmann M: Androgen receptor structure, function and biology: From bench to bedside. Clin Biochem Rev 37: 3-15, 2016.

25. Veldscholte J, Berrevoets CA, Zegers ND, van der Kwast TH, Grootegoed JA and Mulder E: Hormone-induced dissociation of the androgen receptor-heat-shock protein complex: Use of a new monoclonal antibody to distinguish transformed from nontransformed receptors. Biochemistry 31: 7422-7430, 1992.

26. van der Steen T, Tindall DJ and Huang H: Posttranslational modification of the androgen receptor in prostate cancer. Int J Mol Sci 14: 14833-14859, 2013

27. Boam T: Anti-androgenic effects of flavonols in prostate cancer. Ecancermedicalscience 9: 585, 2015.

28. D'Archivio M, Filesi C, Di Benedetto R, Gargiulo R, Giovannini C and Masella R: Polyphenols, dietary sources and bioavailability. Ann Ist Super Sanita 43: 348-361, 2007.

29. Trebatická J and Duračková Z: Psychiatric disorders and polyphenols: Can they be helpful in therapy? Oxid Med Cell Longev 2015: 248529, 2015.

30. Crozier A, Jaganath IB and Clifford MN: Phenols, polyphenols and tannins: An overview, in plant secondary metabolites: Occurrence, structure and role in the human diet, Crozier A, Clifford MN and Ashihara H, (eds), Oxford, Blackwell Publishing Ltd, pp1-24, 2006.

31. Cassidy A and Minihane AM: The role of metabolism (and the microbiome) in defining the clinical efficacy of dietary flavonoids. Am J Clin Nutr 105: 10-22, 2017.

32. Adegbola P, Aderibigbe I, Hammed W and Omotayo T: Antioxidant and anti-inflammatory medicinal plants have potential role in the treatment of cardiovascular disease: A review. Am J Cardiovasc Dis 7: 19-32, 2017. 
33. Barbieri R, Coppo E, Marchese A, Daglia M, Sobarzo-Sánchez E, Nabavi SF and Nabavi SM: Phytochemicals for human disease: An update on plant-derived compounds antibacterial activity. Microbiol Res 196: 44-68, 2017.

34. Crozier A, Jaganath IB and Clifford MN: Dietary phenolics: Chemistry, bioavailability and effects on health. Nat Prod Rep 26: 1001-1043, 2009.

35. Costa SL, Silva VD, Dos Santos Souza C, Santos CC, Paris I, Muñoz P and Segura-Aguilar J: Impact of plant-derived flavonoids on neurodegenerative diseases. Neurotox Res 30: 41-52, 2016.

36. Wang J, Tang L and Wang JS: Biomarkers of dietary polyphenols in cancer studies: Current evidence and beyond. Oxid Med Cell Longev 2015: 732302, 2015.

37. Hilakivi-Clarke L, Andrade JE and Helferich W: Is soy consumption good or bad for the breast? J Nutr 140: 2326S-2334S, 2010.

38. Setchell KD, Brown NM, Desai PB, Zimmer-Nechimias L, Wolfe B, Jakate AS, Creutzinger V and Heubi JE: Bioavailability, disposition, and dose-response effects of soy isoflavones when consumed by healthy women at physiologically typical dietary intakes. J Nutr 133: 1027-1035, 2003.

39. Mondot $\mathrm{S}$ and Lepage $\mathrm{P}$ : The human gut microbiome and its dysfunctions through the meta-omics prism. Ann N Y Acad Sci 1372: 9-19, 2016.

40. Landete JM, Arqués J, Medina M, Gaya P, de Las Rivas B and Muñoz R: Bioactivation of phytoestrogens: Intestinal bacteria and health. Crit Rev Food Sci Nutr 56: 1826-1843, 2016.

41. Rafii F: The role of colonic bacteria in the metabolism of the natural isoflavone daidzin to equol. Metabolites 5: 56-73, 2015.

42. Heinonen SM, Hoikkala A, Wähälä $K$ and Adlercreutz $H$ : Metabolism of the soy isoflavones daidzein, genistein and glycitein in human subjects. Identification of new metabolites having an intact isoflavonoid skeleton. J Steroid Biochem Mol Biol 87: 285-299, 2003.

43. Pilšáková L, Riečanský I and Jagla F: The physiological actions of isoflavone phytoestrogens. Physiol Res 59: 651-664, 2010.

44. Manach C, Williamson G, Morand C, Scalbert A and Rémésy C: Bioavailability and bioefficacy of polyphenols in humans. I. Review of 97 bioavailability studies. Am J Clin Nutr 81 (Suppl 1): 230S-242S, 2005

45. Barnes S: The biochemistry, chemistry and physiology of the isoflavones in soybeans and their food products. Lymphat Res Biol 8: 89-98, 2010.

46. Murphy PA, Barua K and Hauck CC: Solvent extraction selection in the determination of isoflavones in soy foods. J Chromatogr B 777: 129-138, 2002

47. Bai W, Wang $C$ and Ren C: Intakes of total and individual flavonoids by US adults. Int J Food Sci Nutr 65: 9-20, 2014.

48. Van Erp-Baart MA, Brants HA, Kiely M, Mulligan A, Turrini A, Sermoneta C, Kilkkinen A and Valsta LM: Isoflavone intake in four different European countries: The VENUS approach. Br J Nutr 89 (Suppl 1): S25-S30, 2003.

49. Sureda A, Sanches Silva A, Sánchez-Machado DI, López-Cervantes J, Daglia M, Nabavi SF and Nabavi SM: Hypotensive effects of genistein: From chemistry to medicine. Chem Biol Interact 268: 37-46, 2017.

50. Rahman Mazumder MA and Hongsprabhas P: Genistein as antioxidant and antibrowning agents in in vivo and in vitro: A review. Biomed Pharmacother 82: 379-392, 2016.

51. Messina MJ, Persky V, Setchell KD and Barnes S: Soy intake and cancer risk: A review of the in vitro and in vivo data. Nutr Cancer 21: 113-131, 1994

52. Baxa DM, Luo X and Yoshimura FK: Genistein induces apoptosis in T lymphoma cells via mitochondrial damage. Nutr Cancer 51: 93-101, 2005.

53. Baxa DM and Yoshimura FK: Genistein reduces NF-kappa B in T lymphoma cells via a caspase-mediated cleavage of I kappa B alpha. Biochem Pharmacol 66: 1009-1018, 2003.

54. Seo YJ, Kim BS, Chun SY, Park YK, Kang KS and Kwon TG: Apoptotic effects of genistein, biochanin-A and apigenin on LNCaP and PC-3 cells by p21 through transcriptional inhibition of polo-like kinase-1. J Korean Med Sci 26: 1489-1494, 2011.

55. Shen JC, Klein RD, Wei Q, Guan Y, Contois JH, Wang TT, Chang S and Hursting SD: Low-dose genistein induces cyclin-dependent kinase inhibitors and G(1) cell-cycle arrest in human prostate cancer cells. Mol Carcinog 29: 92-102, 2000.

56. Majid S, Kikuno N, Nelles J, Noonan E, Tanaka Y, Kawamoto K, Hirata H, Li LC, Zhao H, Okino ST, et al: Genistein induces the p21WAF1/CIP1 and p16INK4a tumor suppressor genes in prostate cancer cells by epigenetic mechanisms involving active chromatin modification. Cancer Res 68: 2736-2744, 2008.
57. Agarwal R: Cell signaling and regulators of cell cycle as molecular targets for prostate cancer prevention by dietary agents. Biochem Pharmacol 60: 1051-1059, 2000.

58. Wang BF, Wang JS, Lu JF, Kao TH and Chen BH: Antiproliferation effect and mechanism of prostate cancer cell lines as affected by isoflavones from soybean cake. J Agric Food Chem 57: 2221-2232, 2009

59. Li W, Frame LT, Hoo KA, Li Y, D'Cunha N and Cobos E: Genistein inhibited proliferation and induced apoptosis in acute lymphoblastic leukemia, lymphoma and multiple myeloma cells in vitro. Leuk Lymphoma 52: 2380-2390, 2011.

60. Guo Y, Wang S, Hoot DR and Clinton SK: Suppression of VEGF-mediated autocrine and paracrine interactions between prostate cancer cells and vascular endothelial cells by soy isoflavones. J Nutr Biochem 18: 408-417, 2007.

61. Li Y, Che M, Bhagat S, Ellis KL, Kucuk O, Doerge DR, Abrams J, Cher ML and Sarkar FH: Regulation of gene expression and inhibition of experimental prostate cancer bone metastasis by dietary genistein. Neoplasia 6: 354-363, 2004.

62. Li Y and Sarkar FH: Down-regulation of invasion and angiogenesis-related genes identified by cDNA microarray analysis of PC3 prostate cancer cells treated with genistein. Cancer Lett 186: 157-164, 2002

63. Sargeant P, Farndale RW and Sage SO: The tyrosine kinase inhibitors methyl 2,5-dihydroxycinnamate and genistein reduce thrombin-evoked tyrosine phosphorylation and Ca2+ entry in human platelets. FEBS Lett 315: 242-246, 1993.

64. Sathyamoorthy N and Wang TT: Differential effects of dietary phyto-oestrogens daidzein and equol on human breast cancer MCF-7 cells. Eur J Cancer 33: 2384-2389, 1997.

65. Getek M,Czech N, Muc-Wierzgoń M, Grochowska-Niedworok E, Kokot $\mathrm{T}$ and Nowakowska-Zajdel E: The active role of leguminous plant components in type 2 diabetes. Evid Based Complement Alternat Med 2014: 293961, 2014.

66. Mitchell JH, Gardner PT, McPhail DB, Morrice PC, Collins AR and Duthie GG: Antioxidant efficacy of phytoestrogens in chemical and biological model systems. Arch Biochem Biophys 360: 142-148, 1998.

67. Kang KA, Zhang R, Piao MJ, Lee KH, Kim BJ, Kim SY, Kim HS, Kim DH, You HJ and Hyun JW: Inhibitory effects of glycitein on hydrogen peroxide induced cell damage by scavenging reactive oxygen species and inhibiting c-Jun N-terminal kinase. Free Radic Res 41: 720-729, 2007.

68. Ziaei S and Halaby R: Dietary isoflavones and breast cancer risk. Medicines (Basel) 4: pii: E18, 2017.

69. Vitale DC, Piazza C, Melilli B, Drago F and Salomone S: Isoflavones: Estrogenic activity, biological effect and bioavailability. Eur J Drug Metab Pharmacokinet 38: 15-25, 2013.

70. Couse JF, Lindzey J, Grandien K, Gustafsson JA and Korach KS: Tissue distribution and quantitative analysis of estrogen receptor-alpha (ERalpha) and estrogen receptor-beta (ERbeta) messenger ribonucleic acid in the wild-type and ERalpha-knockout mouse. Endocrinology 138: 4613-4621, 1997.

71. Lee JY, Kim HS and Song YS: Genistein as a potential anticancer agent against ovarian cancer. J Tradit Complement Med 2: 96-104, 2012

72. Mahmoud AM, Al-Alem U, Ali MM and Bosland MC: Genistein increases estrogen receptor beta expression in prostate cancer via reducing its promoter methylation. J Steroid Biochem Mol Biol 152: 62-75, 2015.

73. Fixemer T, Remberger K and Bonkhoff H: Differential expression of the estrogen receptor beta (ERbeta) in human prostate tissue, premalignant changes, and in primary, metastatic, and recurrent prostatic adenocarcinoma. Prostate 54: 79-87, 2003.

74. Kuiper GG, Lemmen JG, Carlsson B, Corton JC, Safe SH, van der Saag PT, van der Burg B and Gustafsson JA: Interaction of estrogenic chemicals and phytoestrogens with estrogen receptor beta. Endocrinology 139: 4252-4263, 1998.

75. Banerjee S, Li Y, Wang Z and Sarkar FH: Multi-targeted therapy of cancer by genistein. Cancer Lett 269: 226-242, 2008.

76. An J, Tzagarakis-Foster C, Scharschmidt TC, Lomri N and Leitman DC: Estrogen receptor beta-selective transcriptional activity and recruitment of coregulators by phytoestrogens. J Biol Chem 276: 17808-17814, 2001

77. Muthyala RS, Ju YH, Sheng S, Williams LD, Doerge DR, Katzenellenbogen BS, Helferich WG and Katzenellenbogen JA: Equol, a natural estrogenic metabolite from soy isoflavones: Convenient preparation and resolution of R- and S-equols and their differing binding and biological activity through estrogen receptors alpha and beta. Bioorg Med Chem 12: 1559-1567, 2004. 
78. Setchell KD, Clerici C, Lephart ED, Cole SJ, Heenan C, Castellani D, Wolfe BE, Nechemias-Zimmer L, Brown NM, Lund TD, et al: S-equol, a potent ligand for estrogen receptor beta, is the exclusive enantiomeric form of the soy isoflavone metabolite produced by human intestinal bacterial flora. Am J Clin Nutr 81: 1072-1079, 2005.

79. Song TT, Hendrich S and Murphy PA: Estrogenic activity of glycitein, a soy isoflavone. J Agric Food Chem 47: 1607-1610, 1999.

80. Wang H, Li J, Gao Y, Xu Y, Pan Y, Tsuji I, Sun ZJ and Li XM: Xeno-oestrogens and phyto-oestrogens are alternative ligands for the androgen receptor. Asian JAndrol 12: 535-547, 2010.

81. Lund TD, Munson DJ, Haldy ME, Setchell KD, Lephart ED and Handa RJ: Equol is a novel anti-androgen that inhibits prostate growth and hormone feedback. Biol Reprod 70: 1188-1195, 2004

82. Itsumi M, Shiota M, Takeuchi A, Kashiwagi E, Inokuchi J, Tatsugami K, Kajioka S, Uchiumi T, Naito S, Eto $M$ and Yokomizo A: Equol inhibits prostate cancer growth through degradation of androgen receptor by S-phase kinase-associated protein 2. Cancer Sci 107: 1022-1028, 2016.

83. Pratt WB and Toft DO: Steroid receptor interactions with heat shock protein and immunophilin chaperones. Endocr Rev 18: 306-360, 1997.

84. Basak S, Pookot D, Noonan EJ and Dahiya R: Genistein down-regulates androgen receptor by modulating HDAC6-Hsp90 chaperone function. Mol Cancer Ther 7: 3195-3202, 2008.

85. Chen L, Meng S, Wang H, Bali P, Bai W, Li B, Atadja P, Bhalla KN and $\mathrm{Wu} \mathrm{J}$ : Chemical ablation of androgen receptor in prostate cancer cells by the histone deacetylase inhibitor LAQ824. Mol Cancer Ther 4: 1311-1319, 2005.

86. Li Y, Wang Z, Kong D, Li R, Sarkar SH and Sarkar FH: Regulation of $\mathrm{Akt} / \mathrm{FOXO} 3 \mathrm{a} / \mathrm{GSK}-3 \mathrm{beta} / \mathrm{AR}$ signaling network by isoflavone in prostate cancer cells. J Biol Chem 283: 27707-27716, 2008.

87. Lazarevic B, Karlsen SJ and Saatcioglu F: Genistein differentially modulates androgen-responsive gene expression and activates JNK in LNCaP cells. Oncol Rep 19: 1231-1235, 2008.

88. Maggiolini M, Vivacqua A, Carpino A, Bonofiglio D, Fasanella G, Salerno M, Picard D and Andó S: The mutant androgen receptor T877A mediates the proliferative but not the cytotoxic dose-dependent effects of genistein and quercetin on human LNCaP prostate cancer cells. Mol Pharmacol 62: 1027-1035, 2002

89. Gao S, Liu GZ and Wang Z: Modulation of androgen receptor-dependent transcription by resveratrol and genistein in prostate cancer cells. Prostate 59: 214-225, 2004.

90. Mahmoud AM, Zhu T, Parray A, Siddique HR, Yang W, Saleem M and Bosland MC: Differential effects of genistein on prostate cancer cells depend on mutational status of the androgen receptor. PLoS One 8: e78479, 2013.

91. Veldscholte J, Ris-Stalpers C, Kuiper GG, Jenster G, Berrevoets C, Claassen E, van Rooij HC, Trapman J, Brinkmann AO and Mulder E: A mutation in the ligand binding domain of the androgen receptor of human LNCaP cells affects steroid binding characteristics and response to anti-androgens. Biochem Biophys Res Commun 173: 534-540, 1990

92. Weng C, Cai J, Wen J, Yuan H, Yang K, Imperato-McGinley J and Zhu YS: Differential effects of estrogen receptor ligands on regulation of dihydrotestosterone-induced cell proliferation in endothelial and prostate cancer cells. Int J Oncol 42: 327-337, 2013

93. Takahashi Y, Hursting SD, Perkins SN, Wang TC and Wang TT: Genistein affects androgen-responsive genes through both androgen- and estrogen-induced signaling pathways. Mol Carcinog 45: 18-25, 2006

94. Wang J, Eltoum IE and Lamartiniere CA: Genistein alters growth factor signalling in transgenic prostate model (TRAMP). Mol Cell Endocrinol 219: 171-180, 2004.

95. Lateef A, Khan AQ, Tahir M, Khan R, Rehman MU, Ali F, Hamiza OO and Sultana S: Androgen deprivation by flutamide modulates uPAR, MMP-9 expressions, lipid profile, and oxidative stress: Amelioration by daidzein. Mol Cell Biochem 374: 49-59, 2013

96. Loutchanwoot P, Srivilai P and Jarry H: Lack of anti-androgenic effects of equol on reproductive neuroendocrine function in the adult male rat. Horm Behav 65: 22-31, 2014.

97. Legg RL, Tolman JR, Lovinger CT, Lephart ED, Setchell KD and Christensen MJ: Diets high in selenium and isoflavones decrease androgen-regulated gene expression in healthy rat dorsolateral prostate. Reprod Biol Endocrinol 6: 57, 2008

98. Onozawa M, Fukuda K, Ohtani M, Akaza H, Sugimura T and Wakabayashi K: Effects of soybean isoflavones on cell growth and apoptosis of the human prostatic cancer cell line LNCaP. Jpn J Clin Oncol 28: 360-363, 1998.
99. Davis JN, Muqim N, Bhuiyan M, Kucuk O, Pienta KJ and Sarkar FH: Inhibition of prostate specific antigen expression by genistein in prostate cancer cells. Int J Oncol 16: 1091-1097, 2000

100. Peternac D, Klima I, Cecchini MG, Schwaninger R, Studer UE and Thalmann GN: Agents used for chemoprevention of prostate cancer may influence PSA secretion independently of cell growth in the $\mathrm{LNCaP}$ model of human prostate cancer progression. Prostate 68: 1307-1318, 2008

101. Hussain M, Banerjee M, Sarkar FH, Djuric Z, Pollak MN, Doerge D, Fontana J, Chinni S, Davis J, Forman J, et al: Soy isoflavones in the treatment of prostate cancer. Nutr Cancer 47: $111-117,2003$

102. Kumar NB, Cantor A, Allen K, Riccardi D, Besterman-Dahan K, Seigne J, Helal M, Salup R and Pow-Sang J: The specific role of isoflavones in reducing prostate cancer risk. Prostate 59: 141-147, 2004

103. Dalais FS, Meliala A, Wattanapenpaiboon N, Frydenberg M, Suter DA, Thomson WK and Wahlqvist ML: Effects of a diet rich in phytoestrogens on prostate-specific antigen and sex hormones in men diagnosed with prostate cancer. Urology 64: 510-515, 2004.

104. Schröder FH, Roobol MJ,Boevé ER, de MutsertR,Zuijdgeest-van Leeuwen SD, Kersten I, Wildhagen MF and van Helvoort A Randomized, double-blind, placebo-controlled crossover study in men with prostate cancer and rising PSA: Effectiveness of a dietary supplement. Eur Urol 48: 922-931, 2005.

105. Kranse R, Dagnelie PC, van Kemenade MC, de Jong FH, Blom JH, Tijburg LB, Weststrate JA and Schröder FH: Dietary intervention in prostate cancer patients: PSA response in a randomized double-blind placebo-controlled study. Int J Cancer 113: 835-840, 2005.

106. Vaishampayan U, Hussain M, Banerjee M, Seren S, Sarkar FH, Fontana J, Forman JD, Cher ML, Powell I, Pontes JE and Kucuk O: Lycopene and soy isoflavones in the treatment of prostate cancer. Nutr Cancer 59: 1-7, 2007.

107. Grainger EM, Schwartz SJ, Wang S, Unlu NZ, Boileau TW, Ferketich AK, Monk JP, Gong MC, Bahnson RR, DeGroff VL and Clinton SK: A combination of tomato and soy products for men with recurring prostate cancer and rising prostate specific antigen. Nutr Cancer 60: 145-154, 2008.

108. Hamilton-Reeves JM, Rebello SA, Thomas W, Kurzer MS and Slaton JW: Effects of soy protein isolate consumption on prostate cancer biomarkers in men with HGPIN, ASAP, and low-grade prostate cancer. Nutr Cancer 60: 7-13, 2008.

109. Pendleton JM, Tan WW, Anai S, Chang M, Hou W, Shiverick KT and Rosser CJ: Phase II trial of isoflavone in prostate-specific antigen recurrent prostate cancer after previous local therapy. BMC Cancer 8: 132, 2008

110. Kumar NB, Kang L, Pow-Sang J, Xu P, Allen K, Riccardi D, Besterman-Dahan K and Krischer JP: Results of a randomized phase I dose-finding trial of several doses of isoflavones in men with localized prostate cancer: Administration prior to radical prostatectomy. J Soc Integr Oncol 8: 3-13, 2010.

111. deVere White RW, Tsodikov A, Stapp EC, Soares SE, Fujii H and Hackman RM: Effects of a high dose, aglycone-rich soy extract on prostate-specific antigen and serum isoflavone concentrations in men with localized prostate cancer. Nutr Cancer 62: 1036-1043, 2010.

112. Kwan W, Duncan G, Van Patten C, Liu M and Lim J: A phase II trial of a soy beverage for subjects without clinical disease with rising prostate-specific antigen after radical radiation for prostate cancer. Nutr Cancer 62: 198-207, 2010.

113. Lazarevic B, Boezelijn G, Diep LM, Kvernrod K, Ogren O, Ramberg H, Moen A, Wessel N, Berg RE,Egge-Jacobsen W, et al: Efficacy and safety of short-term genistein intervention in patients with localized prostate cancer prior to radical prostatectomy: A randomized, placebo-controlled, double-blind Phase 2 clinical trial. Nutr Cancer 63: 889-898, 2011

114. Hamilton-Reeves JM, Banerjee S, Banerjee SK, Holzbeierlein JM, Thrasher JB, Kambhampati S, Keighley J and Van Veldhuizen P: Short-term soy isoflavone intervention in patients with localized prostate cancer: A randomized, double-blind, placebo-controlled trial. PLoS One 8: e68331, 2013.

115. van Die MD, Bone KM, Emery J, Williams SG, Pirotta MV and Paller CJ: Phytotherapeutic interventions in the management of biochemically recurrent prostate cancer: A systematic review of randomised trials. BJU Int 117 (Suppl 4): S17-S34, 2016.

116. van Die MD, Bone KM, Williams SG and Pirotta MV: Soy and soy isoflavones in prostate cancer: A systematic review and meta-analysis of randomized controlled trials. BJU Int 113: E119-E130, 2014 
117. Posadzki P, Lee MS, Onakpoya I, Lee HW, Ko BS and Ernst E: Dietary supplements and prostate cancer: A systematic review of double-blind, placebo-controlled randomised clinical trials. Maturitas 75: 125-130, 2013

118. Zhu Y, Xu H, Li M, Gao Z, Huang J, Liu L, Huang X and Li Y: Daidzein impairs Leydig cell testosterone production and Sertoli cell function in neonatal mouse testes: An in vitro study. Mol Med Rep 14: 5325-5333, 2016.

119. Lehraiki A, Messiaen S, Berges R, Canivenc-Lavier MC, Auger J, Habert R and Levacher C. Antagonistic effects of gestational dietary exposure to low-dose vinclozolin and genistein on rat fetal germ cell development. Reprod Toxicol 31: 424-430, 2011.

120. Caceres S, Silvan G, Martinez-Fernandez L, Illera MJ, Millan P, Monsalve B, Peña L and Illera JC: The effects of isoflavones on androgens and glucocorticoids during puberty on male Wistar rats. Reprod Domest Anim 49: 611-617, 2014.

121. Yi MA, Son HM, Lee JS, Kwon CS, Lim JK, Yeo YK, Park YS and Kim JS. Regulation of male sex hormone levels by soy isoflavones in rats. Nutr Cancer 42: 206-210, 2002.

122. Weber KS, Setchell KD, Stocco DM and Lephart ED: Dietary soy-phytoestrogens decrease testosterone levels and prostate weight without altering $\mathrm{LH}$, prostate 5alpha-reductase or testicular steroidogenic acute regulatory peptide levels in adult male Sprague-Dawley rats. J Endocrinol 170: 591-599, 2001.

123. Kumar NB,KrischerJP, Allen K, RiccardiD,Besterman-Dahan K, Salup R, Kang L, Xu P and Pow-Sang J: A Phase II randomized, placebo-controlled clinical trial of purified isoflavones in modulating steroid hormones in men diagnosed with localized prostate cancer. Nutr Cancer 59: 163-168, 2007.

124. Hamilton-Reeves JM, Vazquez G, Duval SJ, Phipps WR, Kurzer MS and Messina MJ: Clinical studies show no effects of soy protein or isoflavones on reproductive hormones in men: Results of a meta-analysis. Fertil Steril 94: 997-1007, 2010.

125. Adlercreutz H, Höckerstedt K, Bannwart C, Bloigu S, Hämäläinen E, Fotsis T and Ollus A: Effect of dietary components, including lignans and phytoestrogens, on enterohepatic circulation and liver metabolism of estrogens and on sex hormone binding globulin (SHBG). J Steroid Biochem 27: 1135-1144, 1987.
126. Berrino F, Bellati C, Secreto G, Camerini E, Pala V, Panico S, Allegro G and Kaaks R: Reducing bioavailable sex hormones through a comprehensive change in diet: The diet and androgens (DIANA) randomized trial. Cancer Epidemiol Biomarkers Prev 10: 25-33, 2001.

127. Sawada N, Iwasaki M, Inoue M, Sasazuki S, Yamaji T, Shimazu T and Tsugane S; Japan Public Health Center-based Prospective Study Group: Plasma testosterone and sex hormone-binding globulin concentrations and the risk of prostate cancer among Japanese men: A nested case-control study. Cancer Sci 101: 2652-2657, 2010.

128. Tanaka M, Fujimoto K, Chihara Y, Torimoto K, Yoneda T, Tanaka N, Hirayama A, Miyanaga N, Akaza H and Hirao Y: Isoflavone supplements stimulated the production of serum equol and decreased the serum dihydrotestosterone levels in healthy male volunteers. Prostate Cancer Prostatic Dis 12: 247-252, 2009

129. Bae M, Woo M, Kusuma IW, Arung ET, Yang CH and Kim YU: Inhibitory effects of isoflavonoids on rat prostate testosterone 5 $\alpha$-reductase. J Acupunct Meridian Stud 5: 319-322, 2012.

130. Hu GX, Zhao BH, Chu YH, Zhou HY, Akingbemi BT, Zheng ZQ and Ge RS: Effects of genistein and equol on human and rat testicular 3beta-hydroxysteroid dehydrogenase and 17beta-hydroxysteroid dehydrogenase 3 activities. Asian J Androl 12: 519-526, 2010.

131. McVey MJ, Cooke GM and Curran IH: Altered testicular microsomal steroidogenic enzyme activities in rats with lifetime exposure to soy isoflavones. J Steroid Biochem Mol Biol 92: 435-446, 2004.

132. Ohno S, Nakajima Y, Inoue K, Nakazawa $H$ and Nakajin S: Genistein administration decreases serum corticosterone and testosterone levels in rats. Life Sci 74: 733-742, 2003. 